\title{
Study of Application for Excursion Observation Method in Primary School 2nd Grade Social Studies*
}

\author{
Ahmet Ali GAZEL ${ }^{* *} \quad$ Ramazan YILDIRIM $^{* * *}$
}

Received: 05 March 2013

Accepted: 12 October 2013

\begin{abstract}
This study aims to investigate how field trips are conducted at 2nd grade of primary schools as a part of social studies course. Data for this research is compiled from 143 permanent Social Studies teachers working throughout 2011-2012 Education Year in the primary schools of central Kütahya and its districts. Data is compiled by using descriptive search model. In the research, after taking expert opinions, a measuring tool developed by the researcher is used. Data obtained from the research were transferred to computer, and analyses were made. In the analysis of the data, frequency and percentage values have been used to determine the distribution. Also a single factor variance analysis and t-test for independent samples have been used to determine the significance of difference between the variables.

As a result of the research, it has been realized that insufficient importance is given to field trip method in Social Studies lessons. Most of the teachers using this method apply it in spring months. Teachers usually make use of field trips independent from unit/topic to increase the students' motivation, and they generally use verbal expression in the class after tours. The biggest difficulty teachers encounter while using tour-observation method is the students' undisciplined behavior.
\end{abstract}

Key words: Field Trip Method, Social Studies, Teaching Methods

\section{Extended Abstract}

Purpose and importance: Social Studies is a lesson which gives opportunity for students to use their experiences throughout the learning process and interact with the environment. It is necessary for the students to go beyond their limits in the classroom to interact with their environment and use their experiences. This is possible only with an effective use of the field trip method. It is known that teachers have very limited use of this method even though they have the theoretical information about field trip method and when they use it, they do not comply with the steps of the application generally. Solutions should be created by investigating the problems in the usage for this method to be applicable. In this research, it has been tried to develop solutions by determining the problems in the use of the method. The purpose is to make contribution to the use of this method and the processing of the lesson. The research is important for the lesson and the method because it will be accepted as successful by the quality of the contribution it makes to the field trip method.

\footnotetext{
* This work was prepared by abridging from Ramazan Yildirim's master's degree thesis with the same name.

** Prof. Dr., Afyon Kocatepe Üniversitesi, agazel@aku.edu.tr

**** Teacher, Sancaktar İmam Hatip Ortaokulu Altıntaş-Kütahya, rmznyldrm@gmail.com
} 
Method: Descriptive scanning method was used in the research. The subjects of the study consisted of Social Sciences teachers who worked in 2011-2012 education year in primary schools of central Kütahya and its districts. The aim was to reach the whole of the working universe, and choosing a sample was avoided as the research was limited to only Kütahya. The survey tool used in the research was developed by the researcher. Through the process of developing the survey tool; firstly, researches about the usage of field trip method in Social Sciences lesson was searched. Furthermore, the opinion of Social Sciences teachers working in Altıntaş district about field trip method were taken by face to face method. Then, a pool consisting of statements of Social Sciences teachers' expressing their opinion on field trip method was created. Statements directed towards the aim of the research were chosen from this pool of statements in order to be used for the survey tool. Expert opinions were consulted in order to question the content validity. Rearranged in accordance with the expert opinion, the survey tool was applied to 20 Social Sciences teachers who were not involved in the research due to piloting and who carried out at least one excursion with their students. The reliability test of the research was done by transferring the information obtained after piloting. Cronbach's $\alpha$ (Alpha) coefficient was used in the analysis. After taking out the statements which were not functional enough and which lowered the content reliability of the scale, the last form of the scale was developed. The Cronbach's alpha reliability coefficient of the survey tool consisting of 30 questions was found to be 0.91 . The total correlations of the survey tool after the piloting varied between .32 and .86. After applying the survey tool to 75 people in the working universe, the construct validity of the scale was examined. Factor analysis technique was utilized for examining the construct validity. Exploratory factor analysis was used because the aim was to reveal the factor structure of the survey tool. Firstly, the results of the KMO and Bartlett tests were analyzed in the evaluation of whether to use the factor analysis on the data obtained. The results revealed that the data was suitable for the factor analysis as the value obtained from KMO test was approximately 1 (.919) and Barlett test was significant. The next step was to identify whether the survey tool, consisting of 30 substances, was single or multi factored with the application of factor analysis technique. According to the results of the analysis, it was seen that, after removing 12 substances whose value of substance factor load was below 0.40 and whose factor loads had a difference less than 0.10 , the substances in the survey tool gather in 4 factors whose self-worth was bigger than 1 and the load values of the substances changed between .44 and .76 . The total variance these 4 factors explained for the survey tool was \%61. According to this, it was thought to be appropriate to gather the substances in the survey tool in four independent factors. Cronbach's $\alpha$ (Alpha) coefficient, just like after the piloting, was used in the analysis to clarify the reliability of these 4 factors. After the analysis, it was identified that the subdimension Cronbach's alpha reliabilities of “planning”, “orientation”, “problem”, and "satisfaction" were $0.64,0.89,0.91$, and 0.81 respectively. The data obtained from the application were subjected to analysis by transferring them to PC environment. Frequency and percentage values were used to determine the distribution in the analysis of the data of the survey's sub-dimensions; t-test and one-way variant analysis (One- 
Way ANOVA) were used for independent samples to determine the meaning of the difference between the variables; for determining in which groups the difference is, Scheffe test was used in case of the equalities of variances, and Tamhane's T2 test was used in case of the inequalities. Statistically, the significance level in the calculations was accepted as 0.05 .

Results: With this research, opinion of teachers were taken for investigating the usage of excursion observation method in Social Sciences lessons in second grade of Primary Schools, and the aim was to determine whether there is a statistically significant difference among these opinions in terms of gender, age, seniority, career, education level and major variables. Approximately one third of participating teachers have not done any field trips with their students yet. Participating teachers mostly did their trips in spring time and at the end of the education year. The teachers use field trips mostly for increasing the motivation of the students instead of unit/topic and consolidation at the end of unit/topic. After the field trip, mostly oral expression was used in the classroom. Visual expression (picturing) and filling in forms are rarely used. According to Social Sciences teachers, the most frequent difficulty encountered in field trips is the undisciplined behavior of students. The other difficulties are the financial problems of parents in covering the costs of the trips, the heavy legal responsibility of the trips and inadequate time because of the intensive lesson schedule. Teachers are indecisive about whether they are experienced in trips and about taking risks in them. Teachers notify the students about what topic or problems will be observed in the trips. This situation shows that the observation is pre-configured in the trips. Teachers' opinions about the problems encountered in the trips are common, and their participation to the statements about the problems is high. The students' behavior which increases their information intended for the purpose of the trip are welcomed by the teachers. 


\title{
İlköğretim II. Kademe Sosyal Bilgiler Derslerinde Gezi-Gözlem Yönteminin Uygulanma Durumunun İncelenmesi $^{*}$
}

\author{
Ahmet Ali GAZEL ${ }^{* *} \quad$ Ramazan YILDIRIM $^{* * *}$
}

Makale Gönderme Tarihi: 05.Mart.2013

Makale Kabul Tarihi: $12 . E k i m .2013$

\begin{abstract}
ÖZET: Bu araştırma, İlköğretim II. Kademe Sosyal Bilgiler derslerinde gezi-gözlem yönteminin uygulanma durumunun incelenmesi amacıyla yapılmıştır. Araştırmanın verileri 2011-2012 Eğitim-Öğretim yılında, Kütahya merkez ve ilçelerindeki ilköğretim okullarında görev yapan 143 kadrolu Sosyal Bilgiler öğretmeninden betimsel tarama modeli kullanılarak toplanmıştır. Araştırmada uzman görüşleri alındıktan sonra araştırıcı tarafından geliştirilen ölçme aracı kullanılmıştır. Araştırmadan elde edilen veriler bilgisayar ortamına aktarılarak analizler yapılmıştır. Elde edilen verilerin analizinde, dağılımın belirlenmesi amacıyla frekans ve yüzdelik değerleri; değişkenler arasındaki farkın anlamlılı̆̆ını belirlemek amacıyla ilişkisiz örneklemler için t-testi ve tek yönlü varyans analizi kullanılmıştır.

Araştırmanın sonucunda Sosyal Bilgiler derslerinde gezi-gözlem yöntemine yeterince yer verilmediği tespit edilmiştir. Yer veren öğretmenlerin çoğunluğu bu yöntemi bahar aylarında kullanmaktadır. Öğretmenler gözlem gezilerini daha çok üniteden/konudan bağımsız olarak öğrencilerin derse olan motivasyonlarını artırmak için kullanmakta ve gezi sonrası sınıfta daha çok sözlü anlatım etkinliğini kullanmaktadırlar. Öğretmenlerin gözlem gezilerini kullanımda karşılaştıkları en büyük zorluk ise öğrencilerin gezilerdeki disiplinsiz davranışlarıdır.
\end{abstract}

Anahtar Sözcükler: Gezi-Gözlem Yöntemi, Sosyal Bilgiler, Öğretim Yöntemleri

\section{Giriş}

İnsan, içine doğduğu çevreyi tanıma, öğrenme ve ondan değişik amaçlarla yararlanma çabası içindedir (Özçelik, 1981). Bu nedenle birey doğduğu andan itibaren öğrenmeye açıktır. Vatandaşı olduğu ülkenin eğitim sistemi içerisine girene kadar bireyin öğreticilik rolünü ailesi ve yakın çevresi üstlenir. Sistem içerisine girdikten sonra ise öğrenme, programlı ve sistematik hale gelir. Bu nedenle her ülke yetiştirmek istediği vatandaş profiline uygun eğitim sistemleri geliştirir. Geliştirilen bu eğitim sistemleri ise, çağın gereksinimlerine göre değişmekte ve bu değişim yeniden yapılanmayı gerektirmektedir. Sistem içerisindeki ana branş derslerinden biri olan Sosyal Bilgiler dersi de bu değişimden nasibini almaktadır. Bu yapılanma ile birlikte derslerde kullanılacak yeni yöntem ve teknikler eğitim bilimleri içerisindeki yerini almaktır. Bunun yanında geleneksel yöntemler de yeri ve zamanı geldikçe ya bağımsız olarak ya da diğer yöntem ve tekniklerle birlikte kullanılmaya devam etmektedir. Bu yöntemlerden birisi de gezi-gözlem yöntemidir. 2004 yllında kabul edilen yeni ilköğretim Sosyal Bilgiler dersi programına göre dersin, öğrencilerin öğrenme sürecinde deneyimlerini kullanmasına ve çevreyle etkileşim kurmasına olanak sağlaması beklenmektedir. Bu beklenti öğretmenlerin bu yöntemi kullanmasını zorunlu hale getirmektedir. Çünkü öğrencilerin çevreyle etkileşime geçebilmeleri için sinıf

\footnotetext{
* Bu çalışma Ramazan Yıldırım'ın aynı adı taşıyan yüksek lisans tezinden kısaltılarak hazırlanmıștır.

** Prof. Dr., Afyon Kocatepe Üniversitesi, agazel@aku.edu.tr

*** Öğretmen, Sancaktar İmam Hatip Ortaokulu Altıntaş-Kütahya, rmznyldrm@gmail.com
} 
duvarlarının dışına çıkmaları gerekmektedir. Bu da ancak gezi-gözlem yönteminin etkili biçimde kullanılmasıyla mümkün olabilir.

Eğitim sisteminin hedeflerinden birisi sistem içerisine giren öğrencilerde kalıcı öğrenmeler sağlamaktır. Sistem ne kadar kalıcı öğrenme sağlayabiliyorsa o derece başarılı ve amacına hizmet ediyor demektir. Öğrenmelerde kalıcılığı sağlamak için bireyin duyularına hitap etmek gerekir. Öğretim ortamının içerisine ne kadar duyu girerse öğrenme o kadar kalıcıdır. Gezi-gözlem yönteminin kullanıldığı bir öğretim ortamı öğrencilerin işitme, görme, dokunma gibi duyularını harekete geçirir. Bu durum öğrencilerde kalıcı öğrenmelerin meydana gelmesini sağlar. Sosyal Bilgiler dersinin laboratuvarının tarihi ve coğrafi mekânlar olduğu kabul edilirse bu yöntemin öğretmenler tarafından kullanılması öğrencilerin akademik başarılarına kayda değer ölçüde katkı sağlayacaktır.

Sosyal Bilgiler derslerinde gezi-gözlem yöntemi dersin amaçlarına hizmet eder şekilde belirlenecek uygulama basamaklarına riayet edilerek kullanılmalıdır. Aksi durumda yapılan gözlem gezileri sosyal etkinlikler kapsamında yapılan diğer gezilerden farksız olacak ve beklenen sonuçlar alınamayacaktır. $\mathrm{Bu}$ nedenle yöntemin kullanımında karşılaşılan sorunlar, problemler araştırılarak çözüm yolları üretilmelidir. Yine öğretmenlerin yöntemi kullanmada karşılaştıkları engeller ortadan kaldırılmalı ve öğretmenler yöntemi kullanmaları yönünde teşvik edilmelidir. Bu araştırmada yöntemin kullanımında karşılaşılan sorun ve problemler tespit edilmeye çalışılmıştır. Araştırma Sosyal Bilgiler derslerinde gezi-gözlem yönteminin kullanımına katkı sağladığı ölçüde başarılı sayılacağından ders ve yöntem için önem arz etmektedir. Bu doğrultuda Sosyal Bilgiler dersinin işlenişinde önemli bir yöntem olan gezi-gözlem yönteminin kullanımı ile ilgili 2011-2012 eğitim öğretim yılında Kütahya ilindeki ilköğretim okullarında görev yapan 143 kadrolu Sosyal Bilgiler öğretmeninin görüşleri alınmıştır. Amaç alınan görüşler doğrultusunda dersin işlenişine ve yöntemin kullanılmasına katkı sağlamaktır.

\section{Problem}

İlköğretim II. Kademe Sosyal Bilgiler derslerinde Sosyal Bilgiler öğretmenlerinin gezi gözlem yöntemini kullanım amaçları; yöntemi kullanımda karşılaştıkları zorluklar/engeller; gezi sonrası sınıfta düzenledikleri etkinlikler; gezilerin planlama, yönlendirme, sorun ve memnuniyet alt boyutlarına ilişkin görüşleri nelerdir?

\section{Alt Problemler}

1. İlköğretim II. Kademe Sosyal Bilgiler derslerinde gözlem gezilerinin kullanımına ilişkin öğretmen görüşlerinde planlama alt boyutu açısından cinsiyet, yaş, kıdem, kariyer, öğrenim durumu ve mezuniyet alanı değişkenleri bakımından anlamlı bir farklılık var mıdır?

2. İlköğretim II. Kademe Sosyal Bilgiler derslerinde gözlem gezilerinin kullanımına ilişkin öğretmen görüşlerinde öğrencileri yönlendirme alt boyutu açısından cinsiyet, yaş, kıdem, kariyer, öğrenim durumu ve mezuniyet alanı değişkenleri bakımından anlamlı bir farklılık var mıdır? 
3. İlköğretim II. Kademe Sosyal Bilgiler derslerinde gözlem gezilerinin kullanımına ilişkin öğretmen görüşlerinde gezilerde karşılaşılan sorunlar alt boyutu açısından cinsiyet, yaş, kıdem, kariyer, öğrenim durumu ve mezuniyet alanı değişkenleri bakımından anlamlı bir farklılık var mıdır?

4. İlköğretim II. Kademe Sosyal Bilgiler derslerinde gözlem gezilerinin kullanımına ilişkin öğretmen görüşlerinde memnuniyet alt boyutu açısından cinsiyet, yaş, kıdem, kariyer, öğrenim durumu ve mezuniyet alanı değişkenleri bakımından anlamlı bir farklılık var mıdır?

\section{Yöntem}

\section{Araştırmanın Modeli}

$\mathrm{Bu}$ araştırmada İlköğretim II. Kademe Sosyal Bilgiler derslerinde gezi-gözlem yönteminin kullanılmasına ilişkin öğretmen görüşlerini belirlemek amacıyla betimsel tarama modeli kullanılmıştır. Sosyal bilimlerde yaygın olarak kullanılan tarama araştırmaları, geniş gruplar üzerinde yürütülen, gruptaki bireylerin bir olgu ve olayla ilgili olarak görüşlerinin, tutumlarının alındığı, olgu ve olayların betimlenmeye çalışıldığı araştırmalardır (Karakaya, 2009). Bu amaca yönelik olarak tarama araştırmalarında genellikle geniş bir kitleden araştırmacı tarafından belirlenen cevap seçenekleri kullanılarak bilgi toplanır. Genellikle tarama araştırmalarında araştırmacılar, görüşlerin ve özelliklerin neden kaynaklandığından çok örneklemdeki bireyler açısından nasıl dağıldığıyla ilgilenmektedir (Büyüköztürk, Kılıç Çakmak, Akgün, Karadeniz ve Demirel, 2010).

\section{Araştırmanın Evreni}

Araştırmanın evrenini Kütahya ili merkez ve ilçelerindeki ilköğretim okullarında, 2011-2012 eğitim öğretim yılında görev yapan kadrolu Sosyal Bilgiler öğretmenleri oluşturmaktadır. Araştırma Kütahya ili ile sınırlı olduğundan örneklem seçme yoluna gidilmemiş, araştırmanın evreninin tamamına ulaşılmaya çalışılmıştır. Araştırmanın evreni ile ilgili istatistikî bilgiler aşağıdaki tablolarda ayrıntılı olarak açıklanmıştır.

Tablo 1

Araştırmanın Evreni ile İlgili İstatistikî Bilgiler

\begin{tabular}{llc}
\hline Sosyal Bilgiler Öğretmeni & $f$ & $\%$ \\
\hline Toplam öğretmen sayısı ve oranı & 174 & 100 \\
Muhtelif liselerde idarecilik görevini yürüten öğretmen sayısı ve oranı & 6 & 3.4 \\
Aylıksız doğum iznindeki öğretmen sayısı ve oranı & 3 & 1.7 \\
Ön uygulama yapılan öğretmen sayısı ve oranı & 20 & 11.5 \\
Araştırmada değerlendirmeye alınan öğretmen sayısı ve oranı & 145 & 83.4 \\
\hline
\end{tabular}


Tablo 1 incelendiğinde araştırmada değerlendirmeye dâhil edilen öğretmenler araştırmanın evreninin \%83.4'ünü oluşturmaktadır. Bu oran araştırılan konu ile ilgili evren hakkında genel bir kanaate varılabilecek yeterliliğe sahiptir. Ölçme aracı ulaştırılan 145 öğretmenden sadece 2'si ölçme aracını cevaplamak istememiş, diğer 143 öğretmen cevaplandırarak geri göndermiştir. Bu nedenle çalışmadaki analizler 143 öğretmenin verilerine göre yapılmıştır.

Tablo 2

Araştırmanın Evreninin Çeşitli Değişkenlere Göre Dă̆llımı

\begin{tabular}{|c|c|c|c|}
\hline Değişkenler & & $f$ & $\%$ \\
\hline \multirow{2}{*}{ Cinsiyet } & Bay & 96 & 67.1 \\
\hline & Bayan & 47 & 32.9 \\
\hline \multirow{4}{*}{ Yaş } & 25 yaş ve altı & 6 & 4.2 \\
\hline & $26-35$ yaş & 84 & 58.7 \\
\hline & $36-45$ yaş & 44 & 30.8 \\
\hline & $46-55$ yaş & 9 & 6.3 \\
\hline \multirow{5}{*}{$\begin{array}{l}\text { Mesleki } \\
\text { Kidem }\end{array}$} & $1-5$ y1l & 45 & 31.5 \\
\hline & 6-10 y1l & 26 & 18.2 \\
\hline & $11-15$ y1l & 47 & 32.9 \\
\hline & $16-20 \mathrm{y} 1 \mathrm{l}$ & 16 & 11.2 \\
\hline & 21 yıl ve yukarısı & 9 & 6.3 \\
\hline \multirow{3}{*}{$\begin{array}{l}\text { Kariyer } \\
\text { Basamağ }\end{array}$} & Aday öğretmen & 5 & 3.5 \\
\hline & Öğretmen & 118 & 82.5 \\
\hline & Uzman öğretmen & 20 & 14.0 \\
\hline \multirow{3}{*}{$\begin{array}{l}\text { Öğrenim } \\
\text { Durumu }\end{array}$} & Lisans & 136 & 95.1 \\
\hline & Lisansüstü & 5 & 3.5 \\
\hline & Eğitim Enstitüsü & 2 & 1.4 \\
\hline \multirow{6}{*}{$\begin{array}{l}\text { Mezuniyet } \\
\text { Alanı }\end{array}$} & $\begin{array}{l}\text { Sosyal Bilgiler } \\
\text { Öğretmenliği }\end{array}$ & 80 & 55.9 \\
\hline & Tarih Öğretmenliğgi & 37 & 25.9 \\
\hline & $\begin{array}{l}\text { Coğrafya } \\
\text { Öğretmenliği }\end{array}$ & 9 & 6.3 \\
\hline & Tarih Bölümü & 13 & 9.1 \\
\hline & Coğrafya Bölümü & 2 & 1.4 \\
\hline & $\begin{array}{l}\text { Diğer(Eğitim } \\
\text { Enstitüsü) }\end{array}$ & 2 & 1.4 \\
\hline
\end{tabular}

Araştırmanın evreninin çeşitli değişkenlere göre dağılımını içeren tabloya göre; araştırmaya katılan grubun yarısından fazlasını erkek öğretmenler oluşturmaktadır (\%67.1). Yaklaşık olarak araştırmanın evreninin 2/3’ü erkektir. 
Öğretmenlerin çoğunluğunun 26-35 yaş grubunda yer aldığı görülmektedir. Genel bir ifade ile de araştırmanın evreni 26-45 yaş arasındaki öğretmenlerden teşekkül etmiştir. Zira bu grup araştırmanın evreninin \%89.5'ini oluşturmaktadır.

Araştırmanın evreninde mesleki kıdemi 11-15 yıl arasında olan öğretmenler en yüksek orana sahip gruptur (\%32.9). Ancak 1-5 y1l arasında mesleki kıdeme sahip öğretmenlerin oranı da önemli bir paya sahiptir. Bu grup da araştırmanın evreninin \%31.5'ini oluşturmaktadır.

Kariyer basamağı öğretmen olan grup çalışma evreninde önemli bir orana sahiptir (\%82.5). Aday öğretmen oranının azlığı yapılan araştırma lehine bir durumdur. Çünkü aday öğretmenlerin mesleklerinin ilk yıllarında gözlem gezisi yapmış olma ihtimali düşüktür. Yine uzman öğretmen sayısının düşük olduğu da göze çarpmaktadır. Kariyer sınavlarının MEB tarafindan periyodik olarak yapılmamasının bu sonucu ortaya çıkardığı düşünülmektedir. Ayrıca tablodaki bilgiler için şunu da ifade etmek gerekir. 13/08/2005 tarihli ve 25905 sayılı resmi gazetede yayımlanarak yürürlüğe giren MEB Öğretmenlik Kariyer Basamaklarında Yükselme Yönetmeliği’nde öğretmenlik kariyer basamakları, adaylık döneminden sonraki öğretmenlik, uzman öğretmenlik ve başöğretmenlik basamaklarını ifade eder şeklinde tanımlanmıştır. Buradan da anlaşılacağı gibi aday öğretmenlik kariyer basamakları içinde yer almamaktadır. Ancak ülkemizde, öğretmen ihtiyacından dolayı öğretmenlerin adaylık süreci kanun ve yönetmeliklerle çizilen sınırlarda geçmemektedir. Örneğin MEB Aday Memurların Yetiştirilmelerine İlişkin Yönetmeliğe göre aday öğretmenler rehber öğretmen nezaretinde derse girer, müstakil ders veremezler. Ancak bunun uygulanması mümkün görülmemektedir. $\mathrm{Bu}$ nedenle araştırmamızda aday öğretmenlik kariyer başlangıcı olarak kabul edilmiş ve kariyer basamakları içerisinde değerlendirilmiştir.

Araştırmanın evrenindeki öğretmenlerin önemli bir bölümü lisans mezunudur (\%95.1). Lisansüstü mezunu öğretmenlerin oranının ise düşük olduğu görülmektedir (\%3.5).

Görevli öğretmenlerin çoğunluğu Sosyal Bilgiler Öğretmenliği mezunudur (\%55.9). Ancak Tarih Öğretmenliği mezunu olup Sosyal Bilgiler Öğretmeni olarak atanan öğretmenlerin oranının da yüksekliği dikkat çekmektedir (\%25.9).

\section{Veri Toplama Aracı}

Araştırmada kullanılan ölçme aracı araştırmacı tarafından geliştirilmiştir. Ölçme aracının geliştirilme sürecinde; önce Sosyal Bilgiler derslerinde gezi-gözlem yönteminin kullanımı ile ilgili yapılan araştırmalar taranmış bunun yanında Altıntaş ilçesinde görevli Sosyal Bilgiler öğretmenlerinin gezi-gözlem yöntemi ile ilgili görüşleri yüz yüze görüşme yöntemiyle alınmıştır. Ardından Sosyal Bilgiler öğretmenlerinin gezi-gözlem yöntemine ilişkin görüşlerinin ortaya konulmasına yönelik ifadelerden oluşan bir havuz oluşturulmuştur. Bu ifade havuzundan, araştırmanın amacına yönelik olarak toplam 62 ifade ölçme aracında kullanılmak üzere seçilmiştir. Seçilen ifadelerin kapsam geçerliğini sorgulamak amaciyla uzman görüşüne başvurulmuştur. Bu geçerlik türü, ölçme aracı içindeki maddeler veya soruların ölçme aracının ölçmeyi amaçladığı 
konuları dengeli bir şekilde temsil etme derecesidir (Tavşancıl, 2006). Bu doğrultuda iki farklı uzman tarafından değerlendirilen ifadelerden bazıları değiştirilmiş, 7 tanesi ise uzman eleştirilerinden dolayı ölçme aracından çıkarılmıştır.

Toplam 55 ifadeden oluşan ölçme aracı, ön uygulama amacıyla araştırmaya dâhil edilmeyen ve öğrencileriyle en az bir kez gözlem gezisi yapmış 20 Sosyal Bilgiler öğretmenine uygulanmıştır. Baş (2005) ön uygulamayı bir aracın test sürüşüne benzetmektedir. Bu uygulamanın amacı veri toplama (ölçme) aracının nasıl çalıştığını görmektir. Ön uygulamada her bir sorunun etkinliği ve veri toplama (ölçme) aracinın toplam etkinliği değerlendirilir (Yazıcıŏglu ve Erdoğan, 2007). Ön uygulama sonras1 elde edilen veriler bilgisayar ortamına aktarılarak ölçme aracının güvenirlik analizi yapılmıştır. Güvenirlik, testin ölçmek istediği özelliği ne derece doğru ölçtüğü ile ilgilidir (Büyüköztürk vd., 2010). Analizde tek uygulamaya dayalı yöntemlerden Cronbach's $\alpha$ (Alpha) katsayısı kullanılmıştır. Bu katsayı özellikle cevapların derecelendirme ölçeğinden elde edildiği durumlarda (5'li likert tipi ölçekler gibi) sıklıkla kullanılmaktadır. Yeterince işlevsel görülmeyen ve ölçeğin güvenirlik katsayısını düşüren ifadeler ölçekten çıkarıldıktan sonra ölçeğe son şekli verilmiştir. 30 ifadeden oluşan ölçme aracının güvenirliği Cronbach's $\alpha$ (Alpha) $=0.91$ olarak tespit edilmiştir. Alfa katsayısının $0.80 \leq \alpha<1.00$ olması ölçeğin yüksek derecede güvenilir olduğunu göstermektedir (Aktaran: Tavşanc1l, 2006). Ön uygulama sonucunda ölçme aracında yer alan maddelerin toplam korelasyonları .32 ile .86 arasında değişim göstermiştir.

Ölçme aracı çalışma evrenindeki 75 kişiye uygulandıktan sonra ölçeğin yap1 geçerliği incelenmeye çalışılmıştır. Yapı geçerliği, testin ölçülmek istenen davranış bağlamında soyut bir kavramı (faktörü) doğru bir şekilde ölçebilme derecesini gösterir (Büyüköztürk, 2008). Yapı geçerliğini incelemek için faktör analizi tekniğinden yararlanılmıştır. Amacımız ölçme aracının faktör yapısını ortaya çıkartmak olduğundan açımlayıcı faktör analizi tekniği kullanılmıştır. Öncelikle elde edilen verilere faktör analizi uygulanıp uygulanmayacağına ilişkin değerlendirmede KMO ve Bartlett testi sonuçlarına bakılmıştır. KMO testinden elde edilen değerin 1'e yakın (.919) olması ve Barlett testinin anlamlı çıkması, verilerin faktör analizi için uygun olduğunu göstermiştir. Tavşancıl'ın (2006: 50) aktardığına göre bulunan değer 1'e yaklaştıkça "mükemmel", 0.50'nin altında ise "kabul edilemez" olarak yorumlanır (0.90'larda mükemmel, 0.80’lerde çok iyi, 0.70’lerde ve 0.60’larda vasat, 0.50’lerde kötü). Faktör analizi uygulaması ile 30 maddeden oluşan ölçme aracının tek ya da çok faktörlü olup olmadığının belirlenmesine çalışılmıştır. Yapılan analiz sonucunda madde faktör yük değeri 0.40 'ın altında olan ve faktör yükleri arasında 0.10 'dan daha az fark olan 12 madde çıkarıldıktan sonra ölçme aracında yer alan maddelerin öz değeri 1'den büyük olan 4 faktörde toplandığ 1 ve maddelerin faktör yük değerlerinin .44 ile .76 arasında değiştiği görülmüştür. Bu 4 faktörün ölçme aracına ilişkin açıkladıkları toplam varyans \%61.267'dir. Tavşancıl'ın (2006: 48) aktardığına göre sosyal bilimlerde yapılan analizlerde $\% 40$ ile $\% 60$ arasında değişen varyans oranları yeterli kabul edilmektedir. 
Buna göre ölçme aracında yer alan maddelerin birbirinden bağımsız dört faktörde toplanması uygun bulunmuştur. Bunlar:

1. Sosyal Bilgiler öğretmenlerinin gözlem gezilerini planlama ile ilgili görüşleri (planlama alt boyutu)

2. Sosyal Bilgiler öğretmenlerinin gözlem gezilerinde öğrencileri yönlendirme ile ilgili görüşleri (yönlendirme alt boyutu)

3. Sosyal Bilgiler öğretmenlerinin gözlem gezilerinde karşılaşılan sorunlar ile ilgili görüşleri (sorun alt boyutu)

4. Sosyal Bilgiler öğretmenlerinin gözlem gezilerindeki memnuniyetleri ile ilgili görüşleri (memnuniyet alt boyutu)

$\mathrm{Bu} 4$ faktörün güvenirliğini belirlemek için yapılan analizde ön uygulama sonrasında olduğu gibi Cronbach's $\alpha$ (Alpha) katsayısı kullanılmıştır. Yapılan analiz sonrasında "planlama” alt boyutunun güvenirliği Cronbach's $\alpha$ (Alpha) $=0.64$, “yönlendirme” alt boyutunun güvenirliği Cronbach's $\alpha$ (Alpha) $=0.89$, “sorun” alt boyutunun güvenirliği Cronbach's $\alpha$ (Alpha) $=0.91$ ve “memnuniyet” alt boyutunun güvenirliği Cronbach's $\alpha$ (Alpha) $=0.81$ olarak tespit edilmiştir. Alfa katsayısının $0.60 \leq$ $\alpha<0.80$ olması ölçeğin oldukça güvenilir, $0.80 \leq \alpha<1.00$ olması ölçeğin yüksek derecede güvenilir olduğunu göstermektedir (Aktaran: Tavşancıl, 2006).

Yapılan bu çalışmalar sonrasında ölçme aracına son şekli verilmiş ve kullanıma hazır hale getirilmiştir.

\section{Verilerin Toplanması}

Araştırmanın çalışma evrenine dâhil edilen 145 Sosyal Bilgiler öğretmeninin tamamına ölçme aracı ulaştırılmıştır. Ölçme aracı ulaştırılan 145 öğretmenden sadece 2'si ölçme aracını cevaplamak istememiş diğer 143 öğretmen cevaplandırarak geri göndermiştir. $\mathrm{Bu}$ nedenle çalışmadaki analizler 143 öğretmenden elde edilen verilere göre yapılmıştır.

\section{Verilerin Analizi}

Uygulamadan elde edilen veriler bilgisayar ortamına aktarılarak analize tabi tutulmuştur. Aracın alt boyutlarındaki verilerin analizinde dağılımın belirlenmesi amacıyla frekans ve yüzdelik değerleri; değişkenler arasındaki farkın anlamlılığını belirlemek amaciyla ilişkisiz örneklemler için t-testi ve tek yönlü varyans analizi (OneWay ANOVA); farklılığın hangi gruplar arasında olduğunu belirlemek amaciyla varyansların eşitliği halinde Scheffe, eşitsizliği halinde Tamhane's T2 testi kullanılmıştır. İstatistiksel açıdan hesaplamalarda anlamlılık düzeyi 0.05 olarak alınmıştır. Verilerin değerlendirilmesinde aşağıdaki aralık tabloları kullanılmıştır. 
Tablo 3

Puan Aralıklarl

\begin{tabular}{lcc}
\hline Seçenekler & Verilen Puanlar & Puan Aralı̆̆ \\
\hline Hiç Katılmıyorum & 1 & $1.00-1.79$ \\
Katılmıyorum & 2 & $1.80-2.59$ \\
Kararsızım & 3 & $2.60-3.39$ \\
Katılıyorum & 4 & $3.40-4.19$ \\
Tamamen Katıllyorum & 5 & $4.20-5.00$ \\
\hline Hiçbir zaman & 1 & $1.00-1.79$ \\
Çok nadir & 2 & $1.80-2.59$ \\
Ara sıra & 3 & $2.60-3.39$ \\
Sık sik & 4 & $3.40-4.19$ \\
Her zaman & 5 & $4.20-5.00$
\end{tabular}

\section{Bulgular}

\section{Gözlem Gezilerinin Kullanımına İlişkin Bulgular}

Araştırmaya katılan Sosyal Bilgiler öğretmenlerinin öğrencileriyle beraber gözlem gezisi yapma durumlarına ve gözlem gezisini kullandıkları dönemlere göre dağılımları Tablo 4’te verilmiştir.

\section{Tablo 4}

Gözlem Gezisi Yapma Durumu ve Gözlem Gezisinin Kullanıldı̆̆ı Döneme Göre Dă̆̆lım

\begin{tabular}{llcc}
\hline & & $f$ & $\%$ \\
\hline $\begin{array}{l}\text { Sosyal Bilgiler derslerinde öğrencilerle } \\
\text { gözlem gezisi yaptınız mı? }\end{array}$ & Evet & 99 & 69.2 \\
& Hayır & 44 & 30.8 \\
\hline & Konu işlenirken eşzamanlı olarak & 14 & 14.1 \\
& Bahar aylarında & 51 & 51.5 \\
Gözlem gezisini daha çok hangi & Belirli gün ve haftalarda & 6 & 6.1 \\
& Resmi bayramlarda & 1 & 1.0 \\
& Eğitim öğretim yılının sonunda & 23 & 23.2 \\
\hline
\end{tabular}

Tablo 4'te öğretmenlerin \%69.2'sinin öğrencileriyle birlikte gözlem gezisi yaptığı görülmektedir. Öğretmenlerin \%30.8'i ise henüz öğrencileriyle birlikte gözlem gezisi yapmamıştır. Sosyal Bilgiler dersinin olmazsa olmazları arasında sayılan gözlem 
gezilerini henüz kullanmayan öğretmenlerin oranının yüksek olduğu belirtilebilir. Öğrencileriyle en az 1 kez gözlem gezisi yapan öğretmenlerin \%51.5’i gözlem gezisini daha çok bahar aylarında kullanmıştır. Araştırmanın yapıldığı bölgenin iklim koşulları düşünüldüğünde bu durum normal karşılanmalıdır. Bu dönemin tercihi iki açıdan önemlidir. Birincisi bahar ile birlikte havaların ısınmaya başlaması ve öğrencilerin okuldaki motivasyonlarının düşmesi derslerin işleyişini aksatmaktadır. Yapılan geziler ise öğrenciler için ekstra motivasyon sağlamaktadır. Yine bu dönem merkezi sınavlar öncesine denk gelmektedir. Bu nedenle öğrencilerin sınavlar öncesi yaşayabilecekleri stresi en aza indirmede yardımcı olacak gezilerin bu dönemlerde yapılması önem arz etmektedir.

\section{Gözlem Gezilerinin Kullanım Amacına İlişkin Bulgular}

Araştırmaya katılan Sosyal Bilgiler öğretmenlerinin gözlem gezilerini kullanım amaçları ile ilgili istatistikî bilgiler Tablo 5’te verilmiştir.

Tablo 5

Gözlem Gezilerinin Kullanım Amacına İlişkin İstatistikî Bilgiler

\begin{tabular}{|c|c|c|c|c|c|c|c|c|}
\hline & & & 1 & 2 & 3 & 4 & 5 & $\bar{x}$ \\
\hline \multirow{2}{*}{1} & \multirow{2}{*}{$\begin{array}{l}\text { Ünitenin/konunun başlangıcında dikkati çekme } \\
\text { amacıyla kullanırım. }\end{array}$} & $\mathrm{f}$ & 24 & 11 & 33 & 26 & 5 & \multirow{2}{*}{2.76} \\
\hline & & $\%$ & 24.2 & 11.1 & 33.3 & 26.3 & 5.1 & \\
\hline \multirow{2}{*}{2} & \multirow{2}{*}{$\begin{array}{l}\text { Ünitenin/konunun başlangıcında öğrencileri } \\
\text { güdüleme amacıyla kullanırım. }\end{array}$} & $\mathrm{f}$ & 13 & 19 & 32 & 28 & 7 & \multirow{2}{*}{2.96} \\
\hline & & $\%$ & 13.1 & 19.2 & 32.3 & 28.3 & 7.1 & \\
\hline \multirow{2}{*}{3} & \multirow{2}{*}{$\begin{array}{l}\text { Ünitenin/konunun sonunda pekiştirme amacıyla } \\
\text { kullanırım. }\end{array}$} & $\mathrm{f}$ & 10 & 3 & 37 & 34 & 15 & \multirow{2}{*}{3.41} \\
\hline & & $\%$ & 10.1 & 3 & 37.4 & 34.3 & 15.2 & \\
\hline \multirow{2}{*}{4} & \multirow{2}{*}{$\begin{array}{l}\text { Ünitenin/konunun sonunda değerlendirme } \\
\text { amacıyla kullanırım. }\end{array}$} & $\mathrm{f}$ & 17 & 14 & 39 & 17 & 12 & \multirow{2}{*}{2.92} \\
\hline & & $\%$ & 17.2 & 14.1 & 39.4 & 17.2 & 12.1 & \\
\hline \multirow[b]{2}{*}{5} & Üniteden/konudan bağımsız olarak öğrencilerin & $\mathrm{f}$ & 6 & 11 & 34 & 20 & 28 & \multirow[b]{2}{*}{3.53} \\
\hline & $\begin{array}{l}\text { derse olan motivasyonlarını artırmak amacıyla } \\
\text { kullanırım. }\end{array}$ & $\%$ & 6.1 & 11.1 & 34.3 & 20.2 & 28.3 & \\
\hline
\end{tabular}

1=Hiçbir zaman, $2=$ Çok nadir, 3=Ara sıra, 4=Sık sık, 5=Her zaman, $\overline{\mathrm{X}}=$ Ortalama

Tablo 5’e göre öğretmenler gözlem gezisini daha çok üniteden/konudan bağımsız olarak öğrencilerin derse olan motivasyonlarını artırmak amacıyla kullanmaktadır. Yine önemli bir kısım ise ünitenin/konunun sonunda pekiştirme amacıyla kullandığını ifade etmiştir. Bu durum öğretmenlerin gözlem gezilerini en çok kullandıkları dönemin bahar ayları olmasını da destekleyen niteliktedir. 


\section{Gözlem Gezileri Sonrası Sınıfta Düzenlenen Etkinliklere İlişkin Bulgular}

Araştırmaya katılan Sosyal Bilgiler öğretmenlerinin gezi sonrası sınıfta düzenlenen etkinlikleri kullanma sıklıkları ile ilgili istatistikî bilgiler Tablo 6'da verilmiştir.

\section{Tablo 6}

Sosyal Bilgiler Öğretmenlerinin Gezi Sonrası Sinıfta Düzenlenen Etkinlikleri Kullanma Siklı̆̆g

\begin{tabular}{|c|c|c|c|c|c|c|c|c|}
\hline & & & 1 & 2 & 3 & 4 & 5 & $\bar{x}$ \\
\hline \multirow{2}{*}{1} & \multirow{2}{*}{ Sözlü anlatım (tartışma, soru-cevap) } & $\mathrm{f}$ & 4 & 8 & 19 & 39 & 29 & \multirow{2}{*}{3.81} \\
\hline & & $\%$ & 4.0 & 8.1 & 19.2 & 39.4 & 29.3 & \\
\hline \multirow{2}{*}{2} & \multirow{2}{*}{ Yazılı anlatım (kompozisyon yazdırma) } & $\mathrm{f}$ & 10 & 20 & 47 & 13 & 9 & \multirow{2}{*}{2.90} \\
\hline & & $\%$ & 10.1 & 20.2 & 47.5 & 13.1 & 9.1 & \\
\hline \multirow{2}{*}{3} & \multirow{2}{*}{ Görsel anlatım (resim yaptırma) } & $\mathrm{f}$ & 29 & 24 & 23 & 15 & 8 & \multirow{2}{*}{2.48} \\
\hline & & $\%$ & 29.3 & 24.2 & 23.2 & 15.2 & 8.1 & \\
\hline \multirow{2}{*}{4} & \multirow{2}{*}{ Fotoğraf sergisi } & $\mathrm{f}$ & 24 & 24 & 25 & 18 & 8 & \multirow{2}{*}{2.61} \\
\hline & & $\%$ & 24.2 & 24.2 & 25.3 & 18.2 & 8.1 & \\
\hline \multirow{2}{*}{5} & \multirow{2}{*}{ Form doldurtma } & $\mathrm{f}$ & 35 & 36 & 15 & 10 & 3 & \multirow{2}{*}{2.09} \\
\hline & & $\%$ & 35.4 & 36.4 & 15.2 & 10.1 & 3.0 & \\
\hline \multirow{2}{*}{6} & \multirow{2}{*}{ Gezi videolarının izletilmesi } & $\mathrm{f}$ & 19 & 10 & 33 & 22 & 15 & \multirow{2}{*}{3.04} \\
\hline & & $\%$ & 19.2 & 10.1 & 33.3 & 22.2 & 15.2 & \\
\hline
\end{tabular}

$1=$ Hiçbir zaman, $2=$ Çok nadir, 3=Ara sıra, 4=Sık sık, 5=Her zaman, $\overline{\mathrm{X}}=$ Ortalama

Tablo 6’ya göre öğretmenler gezi sonrası sınıfta çoğunlukla sözlü anlatım (tartışma, soru-cevap) etkinliğini kullanmaktadır. Diğer etkinliklere nazaran daha pratik ve hazırlık gerektirmeyen bir etkinlik olması nedeniyle tercih edildiği düşünülmektedir. Öğretmenler tarafından çok nadir tercih edilen etkinlikler ise görsel anlatım (resim yaptırma) ve form doldurtma etkinlikleridir.

Gözlem Gezilerini Kullanımda Karşılaşılan Zorluklara / Engellere İliş̧kin Bulgular

Araştırmaya katılan Sosyal Bilgiler öğretmenlerinin gözlem gezilerini kullanmada karşılaştı̆ğ zorluklar/engeller ile ilgili istatistikî bilgiler Tablo 7’de verilmiştir. 
Tablo 7

Sosyal Bilgiler Öğretmenlerinin Gözlem Gezilerini Kullanmada Karşılaştı̆̆ Zorluklar/Engeller

\begin{tabular}{|c|c|c|c|c|c|c|c|c|}
\hline & & & 1 & 2 & 3 & 4 & 5 & $\overline{\mathrm{X}}$ \\
\hline \multirow{2}{*}{1} & \multirow{2}{*}{$\begin{array}{l}\text { Kalabalık sinıfların yöntemi kullanmaya } \\
\text { elverişli olmaması }\end{array}$} & $\mathrm{f}$ & 24 & 11 & 33 & 26 & 5 & \multirow{2}{*}{2.76} \\
\hline & & $\%$ & 24.2 & 11.1 & 33.3 & 26.3 & 5.1 & \\
\hline \multirow{2}{*}{2} & \multirow{2}{*}{\multicolumn{2}{|c|}{$\begin{array}{lll}\text { Gezi esnasında kaza ve tehlikelerle } & \mathrm{f} \\
\text { karşılaşma olasılığ } 1 & & \end{array}$}} & 5 & 22 & 36 & 29 & 7 & \multirow{2}{*}{3.11} \\
\hline & & & 5.1 & 22.2 & 36.4 & 29.3 & 7.1 & \\
\hline \multirow{2}{*}{3} & \multirow{2}{*}{$\begin{array}{l}\text { Yoğun ders programı nedeniyle zaman } \\
\text { bulamama }\end{array}$} & $\mathrm{f}$ & 10 & 3 & 37 & 34 & 15 & \multirow{2}{*}{3.41} \\
\hline & & $\%$ & 10.1 & 3.0 & 37.4 & 34.3 & 15.2 & \\
\hline \multirow{2}{*}{4} & \multirow{2}{*}{$\begin{array}{l}\text { Okul idaresinin geziler konusunda olumsuz } \\
\text { tutuma sahip olması }\end{array}$} & $\mathrm{f}$ & 10 & 15 & 43 & 19 & 12 & \multirow{2}{*}{3.08} \\
\hline & & $\%$ & 10.1 & 15.2 & 43.4 & 19.2 & 12.1 & \\
\hline \multirow[b]{2}{*}{5} & \multirow{2}{*}{ Gezilerin yasal sorumluluğunun ağır olması } & $\mathrm{f}$ & 6 & 11 & 34 & 20 & 28 & \multirow[b]{2}{*}{3.53} \\
\hline & & $\%$ & 6.1 & 11.1 & 34.3 & 20.2 & 28.3 & \\
\hline \multirow{2}{*}{6} & \multirow{2}{*}{$\begin{array}{l}\text { Gözlem gezisi yapacak uygun mekân } \\
\text { bulamama }\end{array}$} & $\mathrm{f}$ & 25 & 43 & 15 & 10 & 6 & \multirow{2}{*}{2.28} \\
\hline & & $\%$ & 25.3 & 43.4 & 15.2 & 10.1 & 6.1 & \\
\hline \multirow{2}{*}{7} & \multirow{2}{*}{$\begin{array}{l}\text { Velilerin gezi } \\
\text { sıkıntı çekmesi }\end{array}$} & $\mathrm{f}$ & 4 & 4 & 20 & 35 & 36 & \multirow{2}{*}{3.95} \\
\hline & & $\%$ & 4.0 & 4.0 & 20.2 & 35.4 & 36.4 & \\
\hline \multirow{2}{*}{8} & \multirow{2}{*}{$\begin{array}{l}\text { Öğrencilerin } \\
\text { davranışları }\end{array}$} & $\mathrm{f}$ & 0 & 4 & 15 & 43 & 37 & \multirow{2}{*}{4.14} \\
\hline & & $\%$ & .0 & 4.0 & 15.2 & 43.4 & 37.4 & \\
\hline
\end{tabular}

$1=$ Hiçbir zaman, $2=$ Çok nadir, $3=$ Ara sıra, $4=$ Sık sı $k$, 5=Her zaman, $\overline{\mathrm{x}}=$ Ortalama

Tablo 7’de Sosyal Bilgiler öğretmenlerinin gözlem gezilerini neden gereğinden az kullandığıyla ilgili ipuçlarını görmek mümkündür. Öğretmenler, karşılaştıkları en büyük zorluğun öğrencilerin gezilerdeki disiplinsiz davranışları olduğunu beyan etmişlerdir. Yine velilerin gezi masraflarını karşılamada sıkıntı çekmesi ve gezilerin yasal sorumluluğunun ağır olması gözlem gezilerinin uygulanmasında karşılaşılan en önemli engellerdir.

\section{Sosyal Bilgiler Öğretmenlerinin Gözlem Gezileri ile İlgili Görüşlerine İlişkin Bulgular}

$\mathrm{Bu}$ bölüm yapılan açımlayıcı faktör analizi sonrası ortaya çıkan dört alt boyuta göre ele alınmıştır. Bunlardan “planlama” alt boyutu 6 ifadeden, ”yönlendirme” alt boyutu 4 ifadeden, "sorun" alt boyutu 5 ifadeden ve "memnuniyet" alt boyutu 3 ifadeden oluşmaktadır. 
Tablo 8

Sosyal Bilgiler Öğretmenlerinin Gözlem Gezileri ile İlgili Görüşleri İçin Frekans, Yüzde ve Madde Ortalamaları ile Maddelerin Faktör Yükleri

\begin{tabular}{|c|c|c|c|c|c|c|c|c|c|}
\hline & & İfadeler & & 1 & 2 & 3 & 4 & 5 & $\bar{x}$ \\
\hline & 1 & Gezi planı hazırlamak gezide gruba önemli & $\mathrm{f}$ & 3 & 2 & 6 & 40 & 48 & 4.29 \\
\hline & & & $\%$ & 3.0 & 2.0 & 6.1 & 40.4 & 48.5 & \\
\hline & 2 & Öğrencilerin gezi aşamalarını takip & $\mathrm{f}$ & 6 & 9 & 24 & 38 & 22 & 3.61 \\
\hline & & 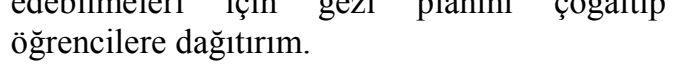 & $\%$ & 6.1 & 9.1 & 24.2 & 38.4 & 22.2 & \\
\hline & 3 & Geziler konusunda deneyimli olduğuma & $\mathrm{f}$ & 5 & 14 & 39 & 33 & 8 & 3.25 \\
\hline$\ddot{\Xi}$ & & & $\%$ & 5.1 & 14.1 & 39.4 & 33.3 & 8.1 & \\
\hline$\frac{\pi}{\pi}$ & 4 & Gezi boyunca kontrollü davranmak adına & $\mathrm{f}$ & 6 & 8 & 5 & 40 & 40 & 4.01 \\
\hline & & 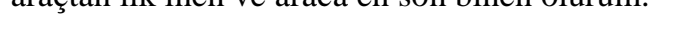 & $\%$ & 6.1 & 8.1 & 5.1 & 40.4 & 40.4 & \\
\hline & 5 & Gezi ile ilgili görselleri, okul gazetesi ve web & $\mathrm{f}$ & 1 & 3 & 8 & 55 & 32 & 4.15 \\
\hline & & $\begin{array}{l}\text { sayrast giol araçrara yaymmatmaktan zevK } \\
\text { alırım. }\end{array}$ & $\%$ & 1.0 & 3.0 & 8.1 & 55.6 & 32.3 & \\
\hline & 6 & Gezilerde bazı riskleri göze almaktan & $\mathrm{f}$ & 16 & 20 & 26 & 27 & 10 & 2.94 \\
\hline & & & $\%$ & 16.2 & 20.2 & 26.3 & 27.3 & 10.1 & \\
\hline & 1 & Yolculuk esnasında öğrencileri, doğayı & $\mathrm{f}$ & 9 & 7 & 7 & 47 & 29 & 3.80 \\
\hline & & & $\%$ & 9.1 & 7.1 & 7.1 & 47.5 & 29.3 & \\
\hline & 2 & Geziden önce hangi konu veya & $\mathrm{f}$ & 12 & 6 & 5 & 50 & 26 & 3.72 \\
\hline & & $\begin{array}{l}\text { sorunarm goziemiene } \\
\text { bildiririm. }\end{array}$ & $\%$ & 12.1 & 6.1 & 5.1 & 50.5 & 26.3 & \\
\hline & 3 & Öğrencileri gezilen mekânlardaki yetkililerden & $\mathrm{f}$ & 6 & 7 & 18 & 51 & 17 & 3.66 \\
\hline & & yönlendiririm. & $\%$ & 6.1 & 7.1 & 18.2 & 51.5 & 17.2 & \\
\hline :ت & 4 & Öğrencilere gezi öncesi beklentileri ile & $\mathrm{f}$ & 9 & 7 & 10 & 50 & 23 & 3.71 \\
\hline$\sum_{0}^{0}$ & & & $\%$ & 9.1 & 7.1 & 10.1 & 50.5 & 23.2 & \\
\hline & 1 & Gezilerde zamanı verimli kullanamamak beni & $\mathrm{f}$ & 8 & 10 & 4 & 52 & 25 & 3.76 \\
\hline & & & $\%$ & 8.1 & 10.1 & 4.0 & 52.5 & 25.3 & \\
\hline & 2 & Öğrencilerin arazide tehlikelerle (güneş & $\mathrm{f}$ & 6 & 8 & 9 & 46 & 30 & 3.86 \\
\hline & & $\begin{array}{l}\text { hayvan tehlikeleri, kayalık ya da uçurum } \\
\text { tehlikeleri gibi) karşılaşma olasılığ beni } \\
\text { tedirgin eder. }\end{array}$ & $\%$ & 6.1 & 8.1 & 9.1 & 46.5 & 30.3 & \\
\hline 串 & 3 & Gezi sonrası gezide görülen aksaklıklar & $\mathrm{f}$ & 10 & 8 & 13 & 49 & 19 & 3.59 \\
\hline & & duyarım. & $\%$ & 10.1 & 8.1 & 13.1 & 49.5 & 19.2 & \\
\hline & 4 & Gezilerde karşılaşılan çevre sorunlarına, & $\mathrm{f}$ & 8 & 11 & 12 & 49 & 19 & 3.60 \\
\hline & & ederim. & $\%$ & 8.1 & 11.1 & 12.1 & 49.5 & 19.2 & \\
\hline & 5 & Gezilerde kurallara aykırı bir öğrenci & $\mathrm{f}$ & 2 & 4 & 3 & 54 & 36 & 4.19 \\
\hline & & uyarıyı yaparım. & $\%$ & 2.0 & 4.0 & 3.0 & 54.5 & 36.4 & \\
\hline
\end{tabular}


Tablo 8'in devamı

\begin{tabular}{|c|c|c|c|c|c|c|c|c|c|}
\hline \multicolumn{4}{|c|}{ İfadeler } & 1 & 2 & 3 & 4 & 5 & $\bar{x}$ \\
\hline \multirow{6}{*}{$\begin{array}{l}\text { 离 } \\
\text { 夏 } \\
\text { 苞 }\end{array}$} & \multirow[t]{2}{*}{1} & \multirow{2}{*}{$\begin{array}{l}\text { Gezi amacına ulaşmış ise dönüş yolculuğunda } \\
\text { kendimi huzurlu hissederim. }\end{array}$} & $\mathrm{f}$ & 2 & 4 & 10 & 30 & 53 & \multirow[t]{2}{*}{4.29} \\
\hline & & & $\%$ & 2.0 & 4.0 & 10.1 & 30.3 & 53.5 & \\
\hline & \multirow[t]{2}{*}{2} & \multirow{2}{*}{$\begin{array}{l}\text { Gezilerde öğrencilerin soru sormalarından ve } \\
\text { görüş belirtmelerinden hoşlanırım. }\end{array}$} & $\mathrm{f}$ & 3 & 8 & 14 & 38 & 36 & \multirow[t]{2}{*}{3.96} \\
\hline & & & $\%$ & 3.0 & 8.1 & 14.1 & 38.4 & 36.4 & \\
\hline & \multirow[t]{2}{*}{3} & \multirow{2}{*}{$\begin{array}{l}\text { Gezi boyunca öğrencilerin gözlemleri ile ilgili } \\
\text { notlar almaları bana mutluluk verir. }\end{array}$} & $\mathrm{f}$ & 3 & 3 & 11 & 53 & 29 & \multirow[t]{2}{*}{4.03} \\
\hline & & & $\%$ & 3.0 & 3.0 & 11.1 & 53.5 & 29.3 & \\
\hline
\end{tabular}

I=Hiç katılmiyorum, 2=Katılmıyorum, 3=Kararsızım, 4=Katıliyorum, 5=Tamamen katıllyorum, $\overline{\mathrm{X}}=$ Ortalama

Sosyal Bilgiler öğretmenlerinin gözlem gezileri ile ilgili görüşleri incelendiğinde;

Öğretmenlerin "Geziler konusunda deneyimli olduğuma inanıyorum." ve "Gezilerde bazı riskleri göze almaktan çekinmem." ifadelerine katılımda kararsız oldukları görülmektedir. Öğretmenlerin geziler konusunda deneyimsiz olmaları derslerde gözlem gezisine yeterince yer verilmediğinin bir kanıtıdır.

Öğretmenlerin gezilerde öğrencileri yönlendirmede etkin rol üstlendikleri görülmektedir. Yapılan gezinin amacına ulaşabilmesi için öğretmenin rehberliği ve yönlendirmesi önemli görülmektedir. Yine öğretmenler gezi öncesinde hangi konu veya sorunların gözlemleneceğini öğrencilere bildirerek gözlemi yapılandırmaktadırlar. Öğrencilerin yetkililerden veya halktan bilgi toplamaları için yönlendirilmesi, onlara özgüven duygusu aşılayacağı gibi sosyalleşmelerine de katkı sağlayacaktır.

Öğretmenlerin gezilerde karşılaşılan sorunlar ile ilgili görüşlerinin ortak olduğu ve yüksek oranlarda bu ifadelere katılım gösterdikleri görülmektedir.

Öğrencilerin gezinin amacına yönelik bilgilerini artırıcı davranışları öğretmenler tarafından memnuniyetle karşılanmaktadır. Gezilerin en yorucu bölümü dönüş yolculuğu bölümüdür. Ancak amacına ulaşmış bir gezi öğretmenin bu anları huzurlu geçirmesini sağlamaktadır.

Planlama alt boyutuna ilişkin analizler. Araştırmanın birinci alt problemi “İlköğretim II. Kademe Sosyal Bilgiler derslerinde gözlem gezilerinin kullanımına ilişkin öğretmen görüşlerinde planlama alt boyutu açısından cinsiyet, yaş, kıdem, kariyer, öğrenim durumu ve mezuniyet alanı değişkenleri bakımından anlamlı bir farklılık var mıdır?" şeklinde ifade edilmiştir. Bu doğrultuda yapılan analizlerin sonuçları aşağıda verilmiştir. 
Tablo 9

Öğretmenlerin Gözlem Gezilerini Planlama ile İlgili Görüşleri Arasındaki Anlamlı Farklılıkları Cinsiyete Göre Tespit Etmek Için Yapılan Analizin Sonuçları

\begin{tabular}{lllll}
\hline Cinsiyet & $n$ & $\overline{\mathrm{x}}$ & ss & $p$ \\
\hline Bay & 61 & 22.86 & 3.65 & $.044^{*}$ \\
Bayan & 38 & 21.31 & 3.72 & \\
\hline \multicolumn{2}{r}{$* p<.05$} & & &
\end{tabular}

1. alt probleme yönelik verilen yanıtların cinsiyete göre aralarında anlamlı bir farklılık gösterip göstermediğini tespit etmek için yapılan t-testinde erkek öğretmenlerin lehine anlamlı bir farklılığın olduğu anlaşılmıştır. Erkek öğretmenlerin gözlem gezilerini planlama ile ilgili görüşleri bayan öğretmenlere göre daha olumludur (Tablo 9).

Tablo 10

Öğretmenlerin Gözlem Gezilerini Planlama ile İlgili Görüşleri Arasındaki Anlamlı Farklılıkları Yaşa, Kıdeme, Kariyere, Öğrenim Durumuna ve Mezuniyet Alanına Göre Tespit Etmek İçin Yapılan Analizlerin Sonuçları

\begin{tabular}{|c|c|c|c|c|c|c|}
\hline Değişkenler & Varyansın kaynağı & Kareler toplamı & $s d$ & Kareler ortalamas 1 & $F$ & $p$ \\
\hline \multirow{3}{*}{ Yaş } & Gruplararası & 20.533 & 2 & 10.266 & .729 & .485 \\
\hline & Gruplariçi & 1351.104 & 96 & 14.074 & & \\
\hline & Toplam & 1371.636 & 98 & & & \\
\hline \multirow{3}{*}{ Kidem } & Gruplararası & 107.631 & 4 & 26.908 & 2.001 & .101 \\
\hline & Gruplariçi & 1264.005 & 94 & 13.447 & & \\
\hline & Toplam & 1371.636 & 98 & & & \\
\hline \multirow{3}{*}{ Kariyer } & Gruplararas1 & 52.528 & 2 & 26.264 & 1.911 & .153 \\
\hline & Gruplariçi & 1319.108 & 96 & 13.741 & & \\
\hline & Toplam & 1371.636 & 98 & & & \\
\hline \multirow{3}{*}{$\begin{array}{l}\text { Öğrenim } \\
\text { Durumu }\end{array}$} & Gruplararası & 5.760 & 2 & 2.880 & .202 & .817 \\
\hline & Gruplariçi & 1365.876 & 96 & 14.228 & & \\
\hline & Toplam & 1371.636 & 98 & & & \\
\hline \multirow{3}{*}{$\begin{array}{l}\text { Mezuniyet } \\
\text { Alanı }\end{array}$} & Gruplararas1 & 115.217 & 5 & 23.043 & 1.706 & .141 \\
\hline & Gruplariçi & 1256.419 & 93 & 13.510 & & \\
\hline & Toplam & 1371.636 & 98 & & & \\
\hline
\end{tabular}


1. alt probleme yönelik verilen yanıtların yaş, kıdem, kariyer, öğrenim durumu ve mezuniyet alanı değişkenlerine göre aralarında anlamlı bir farklılık gösterip göstermediğini tespit etmek için yapılan tek yönlü varyans analizinde, test edilen gruplar arasında anlamlı bir farklılığın olmadığı Tablo 10’un incelenmesi sonucunda anlaşılmıştır ( $p>.05)$.

Yönlendirme alt boyutuna ilişkin analizler. Araştırmanın ikinci alt problemi “İlköğretim II. Kademe Sosyal Bilgiler derslerinde gözlem gezilerinin kullanımına ilişkin öğretmen görüşlerinde öğrencileri yönlendirme alt boyutu açısından cinsiyet, yaş, kıdem, kariyer, öğrenim durumu ve mezuniyet alanı değişkenleri bakımından anlamlı bir farklılık var mıdır?" şeklinde ifade edilmiştir. Bu doğrultuda yapılan analizlerin sonuçları aşağıda verilmiştir.

Tablo 11

Öğretmenlerin Gözlem Gezilerinde Öğrencileri Yönlendirme ile İlgili Görüşleri Arasındaki Anlamlı Farklılıkları Cinsiyete Göre Tespit Etmek Için Yapılan Analizin Sonuçlart

\begin{tabular}{lllll}
\hline Cinsiyet & $n$ & $\overline{\mathrm{x}}$ & SS & $p$ \\
\hline Bay & 61 & 15.62 & 3.33 & $.046^{*}$ \\
Bayan & 38 & 13.78 & 4.89 & \\
\hline & $* p<.05$ & & &
\end{tabular}

2. alt probleme yönelik verilen yanıtların cinsiyete göre aralarında anlamlı bir farklılık gösterip göstermediğini tespit etmek için yapılan t-testinde; test edilen gruplar arasında erkek öğretmenlerin lehine anlamlı bir farklılığın olduğu anlaşılmıştır. Erkek öğretmenlerin gözlem gezilerinde öğrencileri yönlendirme ile ilgili görüşleri bayan öğretmenlere göre daha olumludur (Tablo 11). 
Tablo 12

Öğretmenlerin Gözlem Gezilerinde Öğrencileri Yönlendirme ile Ilgili Görüşleri Arasındaki Anlamlı Farklılıkları Yaşa, Kıdeme, Kariyere, Öğrenim Durumuna ve Mezuniyet Alanına Göre Tespit Etmek İçin Yapılan Analizlerin Sonuçları

\begin{tabular}{|c|c|c|c|c|c|c|}
\hline Değişkenler & Varyansın kaynağı & Kareler toplamı & $s d$ & Kareler ortalamas 1 & $F$ & $p$ \\
\hline \multirow{3}{*}{ Yaş } & Gruplararas1 & 32.758 & 2 & 16.379 & .984 & .378 \\
\hline & Gruplariçi & 1598.596 & 96 & 16.652 & & \\
\hline & Toplam & 1631.354 & 98 & & & \\
\hline \multirow{3}{*}{ Kidem } & Gruplararas1 & 106.522 & 4 & 26.631 & 1.642 & .170 \\
\hline & Gruplariçi & 1524.831 & 94 & 16.222 & & \\
\hline & Toplam & 1631.354 & 98 & & & \\
\hline \multirow{3}{*}{ Kariyer } & Gruplararas1 & 109.860 & 2 & 54.930 & 3.466 & $.035^{*}$ \\
\hline & Gruplariçi & 1521.493 & 96 & 15.849 & & \\
\hline & Toplam & 1631.354 & 98 & & & \\
\hline \multirow{3}{*}{$\begin{array}{l}\text { Öğrenim } \\
\text { Durumu }\end{array}$} & Gruplararası & 53.186 & 2 & 26.593 & 1.618 & .204 \\
\hline & Gruplariçi & 1578.167 & 96 & 16.439 & & \\
\hline & Toplam & 1631.354 & 98 & & & \\
\hline \multirow{3}{*}{$\begin{array}{l}\text { Mezuniyet } \\
\text { Alanı }\end{array}$} & Gruplararası & 132.807 & 5 & 26.561 & 1.648 & .155 \\
\hline & Gruplariçi & 1498.546 & 93 & 16.113 & & \\
\hline & Toplam & 1631.354 & 98 & & & \\
\hline
\end{tabular}

2. alt probleme yönelik verilen yanıtların çeşitli değişkenlere göre aralarında anlamlı bir farklılık gösterip göstermediğini tespit etmek için yapılan tek yönlü varyans analizinde, test edilen gruplar arasında yaş, kıdem, öğrenim durumu ve mezuniyet alanı değişkenlerine göre anlamlı bir farklılığın olmadığı ( $p>.05)$; kariyer değişkenine göre ise kariyer basamağı uzman öğretmen olanlar ile kariyer basamağı öğretmen olanlar arasında anlamlı bir farklılığın olduğu anlaşılmıştır. Kariyer basamağı uzman öğretmen olanların gözlem gezilerinde öğrencileri yönlendirme ile ilgili görüşleri kariyer basamağı öğretmen olanlardan daha olumsuzdur (Tablo 12).

Sorun alt boyutuna ilişkin analizler. Araştırmanın üçüncü alt problemi "İlköğretim II. Kademe Sosyal Bilgiler derslerinde gözlem gezilerinin kullanımına ilişkin öğretmen görüşlerinde gezilerde karşılaşılan sorunlar alt boyutu açısından cinsiyet, yaş, kıdem, kariyer, öğrenim durumu ve mezuniyet alanı değişkenleri bakımından anlamlı bir farklılık var mıdır?” ş̧eklinde ifade edilmiştir. Bu doğrultuda yapılan analizlerin sonuçları aşağıda verilmiştir. 


\section{Tablo 13}

Öğretmenlerin Gezilerde Karşılaşılan Sorunlar ile İlgili Görüşleri Arasındaki Anlamlı Farklılıkları Cinsiyete Göre Tespit Etmek Için Yapılan Analizin Sonuçları

\begin{tabular}{lllll}
\hline Cinsiyet & $n$ & $\overline{\mathrm{x}}$ & SS & $p$ \\
\hline Bay & 61 & 20.03 & 3.82 & $.015^{*}$ \\
Bayan & 38 & 17.42 & 5.68 & \\
\hline \multicolumn{2}{c}{$*_{p}<.05$} & & &
\end{tabular}

3. alt probleme yönelik verilen yanıtların cinsiyete göre aralarında anlamlı bir farklılık gösterip göstermediğini tespit etmek için yapılan t-testinde, test edilen gruplar arasında erkek öğretmenlerin lehine anlamlı bir farklılığın olduğu anlaşılmıştır. Erkek öğretmenlerin gözlem gezilerinde karşılaşılan sorunlar ile ilgili görüşleri, bayan öğretmenlere göre daha olumludur (Tablo 13).

\section{Tablo 14}

Öğretmenlerin Gezilerde Karşılaşılan Sorunlar İle İlgili Görüşleri Arasındaki Anlamlı Farklılıkları Yaşa, Kıdeme, Kariyere, Öğrenim Durumuna ve Mezuniyet Alanına Göre Tespit Etmek İçin Yapılan Analizlerin Sonuçları

\begin{tabular}{lllllll}
\hline Değişkenler & Varyansın kaynağı & Kareler toplamı & sd & Kareler ortalaması & $F$ & $p$ \\
\hline \multirow{2}{*}{ Yaş } & Gruplararası & 42.453 & 2 & 21.227 & .930 & .398 \\
& Gruplariçi & 2190.456 & 96 & 22.817 & & \\
& Toplam & 2232.909 & 98 & & & \\
Kıdem & Gruplararası & 84.304 & 4 & 21.076 & .922 & .455 \\
& Gruplariçi & 2148.605 & 94 & 22.857 & & \\
& Toplam & 2232.909 & 98 & & & \\
Kariyer & Gruplararası & 152.551 & 2 & 76.276 & & $.033^{*}$ \\
& Gruplariçi & 2080.358 & 96 & 21.670 & & \\
& Toplam & 2232.909 & 98 & & & .401 \\
Öğrenim & Gruplararası & 42.153 & 2 & 21.076 & & \\
Durumu & Gruplariçi & 2190.757 & 96 & 22.820 & & \\
& Toplam & 2232.909 & 98 & & & \\
\hline \multirow{3}{*}{$\begin{array}{l}\text { Mezuniyet } \\
\text { Alanı }\end{array}$} & Gruplararası & 138.756 & 5 & 27.751 & & \\
& Gruplariçi & 2094.153 & 93 & 22.518 & & \\
\hline & Toplam & 2232.909 & 98 & & & \\
\hline
\end{tabular}
${ }^{*} p<.05$ 
3. alt probleme yönelik verilen yanıtların çeşitli değişkenlere göre aralarında anlamlı bir farklılık gösterip göstermediğini tespit etmek için yapılan tek yönlü varyans analizinde, test edilen gruplar arasında yaş, kıdem, öğrenim durumu ve mezuniyet alanı değişkenlerine göre anlamlı bir farklılığın olmadığ ${ }_{1}(p>.05)$; kariyer değişkenine göre ise kariyer basamağı uzman öğretmen olanlar ile kariyer basamağı öğretmen olanlar arasında anlamlı bir farklılığın olduğu anlaşılmıştır. Buna göre kariyer basamağı uzman öğretmen olanların gözlem gezilerinde karşılaşılan sorunlar ile ilgili görüşleri kariyer basamağı ögretmen olanlardan daha olumsuzdur (Tablo 14).

Memnuniyet alt boyutuna ilişkin analizler. Araştırmanın dördüncü alt problemi "İlköğretim II. Kademe Sosyal Bilgiler derslerinde gözlem gezilerinin kullanımına ilişkin öğretmen görüşlerinde memnuniyet alt boyutu açısından cinsiyet, yaş, kıdem, kariyer, öğrenim durumu ve mezuniyet alanı değişkenleri bakımından anlamlı bir farklılık var mıdır?" şeklinde ifade edilmiştir. Bu doğrultuda yapılan analizlerin sonuçları aşağıda verilmiştir.

\section{Tablo 15}

Ögrretmenlerin Gözlem Gezilerindeki Memnuniyetleri İle İlgili Görüşleri Arasındaki Anlamlı Farklılıkları Cinsiyete Göre Tespit Etmek Için Yapılan Analizin Sonuçları

\begin{tabular}{lllll}
\hline Cinsiyet & $n$ & $\overline{\mathrm{x}}$ & $S S$ & $p$ \\
\hline Bay & 61 & 12.85 & 1.95 & $.010^{*}$ \\
Bayan & 38 & 11.39 & 2.98 & \\
\hline \multicolumn{2}{r}{$* p<.05$} & & &
\end{tabular}

4. alt probleme yönelik verilen yanıtların cinsiyete göre aralarında anlamlı bir farklılık gösterip göstermediğini tespit etmek için yapılan t-testinde, test edilen gruplar arasında erkek öğretmenlerin lehine anlamlı bir farklılığın olduğu anlaşılmıştır. Erkek öğretmenlerin gözlem gezilerindeki memnuniyetleri ile ilgili görüşleri bayan öğretmenlere göre daha olumludur (Tablo 15). 
Tablo 16

Öğretmenlerin Gözlem Gezilerindeki Memnuniyetleri İle İlgili Görüşleri Arasındaki Anlamlı Farklılıkları Yaşa, Kıdeme, Kariyere, Öğrenim Durumuna ve Mezuniyet Alanına Göre Tespit Etmek Için Yapılan Analizlerin Sonuçları

\begin{tabular}{|c|c|c|c|c|c|c|}
\hline Değişkenler & Varyansın kaynağ 1 & Kareler toplam 1 & $s d$ & Kareler ortalamas 1 & $F$ & $p$ \\
\hline \multirow{3}{*}{ Yaş } & Gruplararası & 3.299 & 2 & 1.650 & .262 & .770 \\
\hline & Gruplariçi & 605.206 & 96 & 6.304 & & \\
\hline & Toplam & 608.505 & 98 & & & \\
\hline \multirow{3}{*}{ Kidem } & Gruplararas1 & 34.059 & 4 & 8.515 & 1.393 & .242 \\
\hline & Gruplariçi & 574.446 & 94 & 6.111 & & \\
\hline & Toplam & 608.505 & 98 & & & \\
\hline \multirow{3}{*}{ Kariyer } & Gruplararası & 39.027 & 2 & 19.513 & 3.289 & $.042^{*}$ \\
\hline & Gruplariçi & 569.478 & 96 & 5.932 & & \\
\hline & Toplam & 608.505 & 98 & & & \\
\hline \multirow{3}{*}{$\begin{array}{l}\text { Öğrenim } \\
\text { Durumu }\end{array}$} & Gruplararası & 5.853 & 2 & 2.926 & .466 & .629 \\
\hline & Gruplariçi & 602.652 & 96 & 6.278 & & \\
\hline & Toplam & 608.505 & 98 & & & \\
\hline \multirow{3}{*}{$\begin{array}{l}\text { Mezuniyet } \\
\text { Alanı }\end{array}$} & Gruplararas1 & 36.200 & 5 & 7.240 & 1.177 & .327 \\
\hline & Gruplariçi & 572.305 & 93 & 6.154 & & \\
\hline & Toplam & 608.505 & 98 & & & \\
\hline
\end{tabular}

4. alt probleme yönelik verilen yanıtların çeşitli değişkenlere göre aralarında anlamlı bir farklılık gösterip göstermediğini tespit etmek için yapılan tek yönlü varyans analizinde, test edilen gruplar arasında yaş, kıdem, öğrenim durumu ve mezuniyet alanı değişkenlerine göre anlamlı bir farklılığın olmadığı ( $p>.05)$; kariyer değişkenine göre ise kariyer basamağı uzman öğretmen olanlar ile kariyer basamağı öğretmen olanlar arasında anlamlı bir farklılığın olduğu anlaşılmıştır. Buna göre kariyer basamağı uzman öğretmen olanların gözlem gezilerindeki memnuniyetleri ile ilgili görüşleri kariyer basamağı ögretmen olanlardan daha olumsuzdur (Tablo 16).

\section{Sonuçlar ve Tartışma}

$\mathrm{Bu}$ araştırma ile İlköğretim II. Kademe Sosyal Bilgiler derslerinde gezi-gözlem yönteminin (veya gözlem gezilerinin) kullanımını incelemek amacıyla öğretmen görüşleri alınmış, bu görüşler arasında cinsiyet, yaş, kıdem, kariyer, öğrenim durumu ve mezuniyet alanı değişkenleri bakımından anlamlı bir farklılığın olup olmadı̆̆ belirlenmeye çalışılmıştır. 
Araştırmaya katılan öğretmenlerin yaklaşık 1/3'ü henüz öğrencileriyle gözlem gezisi yapmamıştır. Mazman'ın (2007) yaptığı araştırmaya göre öğretmenlerin \%39'u, gezi-gözlem metodunu hiç kullanmamışlardır. Çetin, Kuş ve Karatekin (2010), çalışmalarında gezi-gözlem metodunun Sınıf ve Sosyal Bilgiler öğretmenleri tarafından sık kullanılan bir metot olmadığı sonucuna ulaşmışlardır. Taşkaya ve Bal'a (2009) göre sınıf öğretmenlerinin bildiği ancak derste kullanamadığı Sosyal Bilgiler öğretim yöntemlerinin başında gezi-gözlem gelmektedir. Bu sonuçlar ve bizim araştırmamızdan çıkan sonuç Sosyal Bilgiler derslerinde gezi-gözlem yöntemine yeterince yer verilmediğini göstermektedir.

Araştırmaya katılan öğretmenler gözlem gezilerini çoğunlukla bahar aylarında ve eğitim öğretim yılının sonunda kullanmışlardır. Çetin, Kuş ve Karatekin'e (2010) göre, Sınıf ve Sosyal Bilgiler öğretmenleri geziyi konu işlenirken eşzamanlı olarak, belirli gün ve haftalarda ve iklim koşullarının uygun olduğu zamanlarda düzenlemeye gayret etmektedir.

Öğretmenler gözlem gezilerini, daha çok üniteden/konudan bağımsız olarak öğrencilerin derse olan motivasyonlarını artırmak ve ünitenin/konunun sonunda pekiştirme amacıyla kullanmaktadır. Yapılan gözlem gezisi sonrası ise sınıfta daha çok sözlü anlatım (tartışma, soru-cevap) etkinliği kullanılmaktadır. Görsel anlatım (resim yaptırma) ve form doldurtma etkinlikleri ise çok nadir kullanılmaktadır.

Sosyal Bilgiler öğretmenlerine göre, gözlem gezilerini kullanımda en sık karşılaşılan zorluk öğrencilerin gezilerdeki disiplinsiz davranışlarıdır. Velilerin gezi masraflarını karşılamada sıkıntı çekmesi, gezilerin yasal sorumluluğunun ağır olması ve yoğun ders programı nedeniyle zaman bulamama ise diğer sık karşılaşılan zorluklardır. Özay’a (2003) göre, Coğrafya öğretmenlerinin büyük bir çoğunluğu gezi-gözlem yönteminin uygulanmasında idari bir sorunla karşılaşmışlar, ancak velilerden kaynaklanan bir sorunla çok az karşılaşmışlardır. Tunç'a (2006) göre Coğrafya öğretmenleri gezi-gözlem yaparken idari bir sorunla karşılaşmamışlardır. Yine velilerle herhangi bir sorun yaşanmamıştır. Yöntemi kullanmayan öğretmenlerin çoğunluğu ekonomik nedenlerden şikâyetçidir. Ballı'ya (2009) göre, gezi-gözleme başvurmayan öğretmenlerin büyük çoğunluğu ekonomik nedenlerden şikâyetçidir ve birçoğu gezi gözlem yapılırken idari bir takım sorunlarla karşı karşıya kalmıştır. Çetin, Kuş ve Karatekin'e (2010) göre, öğretmenlerin bu yöntemi uygulayamamalarının en temel nedenlerinden birisi ekonomik problemlerdir. Özellikle öğrencilerden para toplayamama, gezilecek yerlerin ücretli olması, araç temin edememeyi ekonomik problemler olarak sıralamışlardır. Taşkaya ve Bal'a (2009) göre, öğretmenlerin yöntemi kullanamama nedenlerinin başında okulun imkânlarının kısıtlı olması gelmektedir. Bütün bu değerlendirmelerde küçük farklılıklar olsa da gezilerde karşılaşılan zorluklar/engeller araştırmamızın sonuçlarıyla benzerlik göstermektedir.

Öğretmenler geziler konusunda deneyimli olup olmamaları ve gezilerde bazı riskleri göze alma konularında kararsızdırlar. Yasal sorumluluğun ağır olması nedeniyle gezilerde risk almak sakıncalı bir durumdur. Maalesef bu riskin alınması gerektiği durumlar da ortaya çıkmaktadır. Örneğin uzak çevreye yapılan gezilerin günübirlik 
yapılması risklidir. Ancak konaklama, yeme içme maliyetlerinin yüksekliği nedeniyle bu geziler çoğu zaman günübirlik yapılmaktadır. Bu durumda gidiş ve dönüş yolculuğu gece yapılmakta gündüz ise dinlenme imkânı bulunamadan gezi programına geçilmektedir. Öğrencilerin yaşları itibariyle bu tempoyu kaldırması zor olmakta ve gezi tam anlamıyla amacına ulaşamamaktadır.

Araştırmaya göre gezide görülen aksaklıklar konusunda öğrencilerin görüşleri alınmakta ve çevre sorunlarına öğrenciler tarafından çözümler getirilmesine imkân verilmektedir. Bu durum öğrencilerin geziye aktif olarak katılımını sağlayacaktır. Aynı zamanda bu uygulama öğrencilerin otantik öğrenme ile bilgi ve beceri edinmesini sağlayacaktır. Otantik öğrenmede amaç, bireyin doğrudan bir konuyu öğrenmesi değil, gerçek dünya problemlerine çözüm üretmesidir (Bektaş ve Horzum, 2010).

Öğretmenler geziden önce hangi konu veya sorunların gözlemleneceğini ögrencilere bildirmektedirler. Bu durum gezilerde gözlemin önceden yapılandırıldığını gösterir. Öğretmenlerin gezilerde karşılaşılan sorunlar ile ilgili görüşleri ortak, sorunlar ile ilgili ifadelere katılımları yüksektir. Öğrencilerin gezinin amacına yönelik bilgilerini artırıcı davranışları öğretmenler tarafından memnuniyetle karşılanmaktadır.

\section{Kaynakça}

Ballı, A. (2009). 9. Sınıf Fiziki Coğrafya Konuları Öğretiminde Gezi Gözlem Yönteminin Önemi (Bağcılar İlçesi Örneği). (Yayınlanmamış yüksek lisans tezi). Marmara Üniversitesi, İstanbul.

Baş, T. (2005). Anket (Nasıl Hazırlanır, Uygulanır, Değerlendirilir?). Ankara: Seçkin Yayınları.

Bektaş, M., \& Horzum, M.B. (2010). Otantik Öğrenme. Ankara: Pegem Akademi.

Büyüköztürk, Ş. (2008). Sosyal Bilimler İçin Veri Analizi El Kitabı (9. baskı). Ankara: Pegem Akademi.

Büyüköztürk, Ş., Kılıç Çakmak, E., Akgün, Ö. E., Karadeniz, Ş., \& Demirel, F. (2010). Bilimsel Araştırma Yöntemleri (5. baskı). Ankara: Pegem Akademi.

Çetin, T., Kuş, Z., \& Karatekin, K. (2010). Sınıf ve Sosyal Bilgiler Öğretmenlerinin Gezi-Gözlem Yöntemine İlişkin Görüşleri. Sosyal Bilimler Araştırmaları Dergisi, 5(2), 158-180.

Karakaya, İ. (2009). Bilimsel Araştırma Yöntemleri. A. TANRIÖĞEN (Ed.), Bilimsel Araştırma Yöntemleri içinde (57-83). Ankara: Anı Yayıncılık.

Mazman, F. (2007). Sosyal Bilgiler Eğitiminde Gezi-Gözlem Metodunun Uygulanmasına İlişkin Bir Araştırma (Tokat Örneği). (Yayınlanmamış yüksek lisans tezi). Gaziosmanpaşa Üniversitesi, Tokat.

Özay, E. (2003). Ortaöğretim Coğrafya Ĕ̆itimi ve Öğretiminde Gezi-Gözlem Metodunun Öğrenci Başarısı Üzerine Etkisi ve Dĭger Öğretim Metodlarlyla Karşılaş̧ırılması. (Yayınlanmamış yüksek lisans tezi). Marmara Üniversitesi, İstanbul. 
Özçelik, D. A. (1981). Araştırma Teknikleri Düzenleme ve Analiz. Ankara: ÜSYM Eğitim Yayınları.

Taşkaya, S. M., \& Bal, T. (2009). Sınıf Öğretmenlerinin Sosyal Bilgiler Öğretim Yöntemlerine İlişkin Görüşleri. Ahmet Keleşoğlu Eğitim Fakültesi Dergisi, Sayı 27, $173-185$.

Tavşanc1l, E. (2006). Tutumların Ölçülmesi ve SPSS ile Veri Analizi (3. bask1). Ankara: Nobel Yayın Dağıtım.

Tunç, S. (2006). Gezi-Gözlem Yönteminin Coğrafya Eğitim Öğretimindeki Önemi, Öğrenci Başarısına Etkisi ve Diğer Öğretim Yöntemleriyle Karşılaştırılması. (Yayınlanmamış yüksek lisans tezi). Gazi Üniversitesi, Ankara.

Yazıcıoğlu, Y., \& Erdoğan, S. (2007). SPSS Uygulamalı Bilimsel Araştırma Yöntemleri (Genişletilmiş 2.Baskl). Ankara: Detay Yayıncılık.

Y1ldırım, R. (2012). Illkögrretim II. Kademe Sosyal Bilgiler Derslerinde Gezi-Gözlem Yönteminin Uygulanma Durumunun İncelenmesi. (Yayınlanmamış yüksek lisans tezi). Afyon Kocatepe Üniversitesi, Afyonkarahisar. 